\title{
Aizanoi Antik Kentinde Bulunan Odeion Yapısının Malzeme Özellikleri ve Hasar Durumunun İncelenmesi
}

\author{
Investigation of the Material Properties and Damages of the Odeion in the Ancient City Aizanoi
}

\author{
Gülçin Kahraman* (D, Seden Acun Özgünler** (D)
}

Öz

Aizanoi Antik kenti Kütahya ili, Çavdarhisar ilçesinde yer almaktadır. Kentteki ilk yerleşim Hellenistik döneme ait olup kent Bizans döneminde de önemini korumuştur. Günümüzde antik kentin çevresinde yerleşik hayat devam etmektedir. Kentin Odeion yapısı MS 1. yüzyılın sonu ya da 2. yüzyılın başlarında Zeus tapınağının güneydoğusunda inşa edilmiştir. Günümüz yerleşim dokusunun kuzeyinde yer alan yapı ilk olarak "bouleuterion" (meclis binası) olarak inşa edilmiştir. MS 4. yüzyılda sahne yapısı da eklenerek "odeiona” (tiyatro ve dinleti yapısı) dönüştürüldüğü düşünülmektedir. Yapı kalıntılarının açığa çıkarılması amacıyla 1998 yılında arkeolojik kazı çalışmalarına başlanılmıştır. 2016 yılına kadar devam eden bu çalışmalarda yapının Bizans döneminde yapılan birtakım müdahaleler geçirdiği ve günümüzde yerleşime ulaşmak amacıyla düzenlenen yol inşa çalışmaları ile büyük oranda hasara uğradığı tespit edilmiştir. Farklı dönemlere ait yapı bölümleri ile onarım müdahaleleri yer alan yapıda devşirme yapı malzemeleri kullanılmıştır. Bu çalışma 2017 ile 2019 yılları arasında yapılan hasar tespit çalışmaları ile birlikte yapının malzeme özelliklerinin belirlenmesi için deneysel çalışmalara göre hazırlanmıştır. Arkeolojik kazı çalışmalarındaki veriler ile malzeme analiz sonuçlarının birlikte değerlendirildiği bu makalede yapının farklı dönemlerine ait malzeme özellikleri, koruma sorunları ve yapının günümüze ulaşabilmesi için yapılan müdahaleler değerlendirilmiştir.

\section{Anahtar Kelimeler}

Odeion, bouleuterion, Aizanoi, yapı malzemesi, koruma sorunları

\begin{abstract}
The ancient city of Aizanoi is located in the Çavdarhisar district of Kütahya province. The city's first settlement dates from the Hellenistic period, and it retained its importance during the Byzantine period. Today, settled life may be found in the vicinity of the ancient city. The odeon of the city was built to the southeast of the Zeus Temple and is presently situated to the north of the residential area. The structure was originally built as a "bouleuterion" toward the end of the first century or the beginning of the second century A.D. It is thought that it was converted to an odeon in the fourth century A.D. by the addition of a stage structure. Archaeological excavations began in 1998 to uncover the remains of the building. During these excavations, which lasted until 2016, it was discovered that the building had undergone several interventions during the Byzantine period and was also seriously damaged by road construction works to reach the, resulting in settlement. The structure has expansions and repairs from different periods, as well as reused building materials. Experimental studies were conducted to determine the material properties of the building, with damage assessment studies carried out between 2017 and 2019. This article presents the data from the archaeological excavations the material properties of the different periods, the conservation problems, and the interventions made to bring the building to its current state.
\end{abstract}

\section{Keywords}

Odeon, bouleuterion, Aizanoi, building materials, conservation problems

* Sorumlu Yazar: Gülçin Kahraman (Dr. Öğr. Üyesi), İstanbul Sabahattin Zaim Üniversitesi, Mühendislik ve Doğa Bilimleri Fakültesi, Mimarlık Bölümü, İstanbul, Türkiye. E-posta: gulcin.kahraman@izu.edu.tr, ORCID: 0000-0002-0074-0514

** Seden Acun Özgünler (Doç. Dr.), İstanbul Teknik Üniversitesi, Mimarlık Fakültesi, Mimarlık Bölümü, İstanbul, Türkiye. E-posta: acunsed@itu.edu.tr, ORCID:0000-0001-5975-5115

Atıf: Kahraman, Gulcin ve Acun-Ozgunler, Seden. “Aizanoi Antik Kentinde Bulunan Odeion Yapısının Malzeme Özellikleri ve Hasar Durumunun İncelenmesi." Art-Sanat, 16(2021): 355-379. https://doi.org/10.26650/artsanat.2021.16.0012 


\section{Extended Summary}

The Greek word odeon is derived from the word ode, which means song, and originates from the Latin word odeum. The odeon is a covered structure that is similar to a small theater, and it is used to host concerts and musicals. Owing to its design schemes and the fact that it is an enclosed space, it is similar to a "bouleuterion" (parliament building).

During Emperor Hadrianus' reign, the ancient city of Aizanoi in Western Anatolia was at its peak. The odeon structure lies to the southeast of the Zeus Temple, west of the Pankelas Stream (Kısıkboğaz Creek), and northwest of Abdullah Özcan Street today. Archaeological excavations of the odeon began in 1998. During excavations in 2001, a substantial portion of the building was unearthed. Through three doorways, the odeon and orchestra connect to the temple courtyard with Doric columns. During the excavations, flooring from another period was discovered under the door thresholds, indicating that the doors were repaired the second building phase. Since the spolia elements in the flooring belong to the early period arch and many coins were during the excavation, this intervention is assumed to have been made in the third century A.D. Lime pit remains and marble fragments dating back to the Middle Byzantine period were discovered near the odeon. These data that the building was destroyed and burned during this period to obtain lime.

It suggests that the rear wall of the structure located southwest of the temple was terraced to connect with the temple courtyard and that this arrangement was made during the late Trajanian period, which was when the courtyard was constructed. During the 2001 excavations, the side steps of the odeon were completed, the cavea section was made accessible, and the building was opened to visitors. To determine the boundaries of the building, the orchestra of the building, the first two rows of its in situ cavea, the traces of the third and fourth rows, the steps rising to the cavea, and the walls of the north and south parodoi were unearthed during the archaeological excavations that was concluded in 2016.

Despite a tremendous degree of damage, the building has survived to this day. The cavea consists of marble steps and sitting rows with beveled edges on the rubble stone foundation base. To characterize the original building materials and assess the damage conditions, material analyses and determinations were performed. The properties of the materials taken from the parts of the building constructed during different periods were discovered to be different.

Stones were used for constructing the building, while lime mortars were used as the binding material. The orchestra was built in a semicircular shape, with marble flooring, which was defined by the existing floor remains. According to the experimental analysis performed on the stone samples obtained from the orchestra floor and the cavea area, both marble materials were dark gray, white-veined, and had strong 
structures, and the values in the physical properties and ignition loss analysis results were similar. The area where the parodoi walls and the cavea met was made of marble blocks, whereas the area where the parodoi and the stage wall met was made of white and gray veined marbles on a rubble stone wall. The floors of the parodoi were covered with marble and lime mortar bedding. The floor sample is white, with thick black veins and a strong structure. According to the laboratory analysis, the marble flooring of the parodoi is different from the marbles taken from the cavea and orchestra floor, and its porosity and compressive strength are lower than those of the other marbles.

The top of the southeast parodoi was covered with spolia marble materials. The parodoi walls are assumed to have been constructed with cut stone blocks, whereas the side corridors were constructed using the opus vittatum technique, or the side corridors were repaired and covered with marbles in their original state.

The marble coverings of the stage of the building did not survive. The stage walls were built with large micritic limestone blocks. There are surface and joint losses on the stage walls due to climatic conditions. The road built right above the stage imposed pressure on the walls owing to its load and traffic density. Furthermore, the vibration of the road damaged the entire structure. During the excavations, collapses were discovered in the wall, and reinforcement works were carried out. Repairs were made at different periods, with the most recent being in 2016 . The interventions were made with lime/cement hybrid mortars.

Water penetration into a structure that has been exposed to rain, snow, or frost causes more damage. During the freeze-thaw cycle, the volume of water moving into the gaps changes because of temperature differences, causing explosions and cracks in building parts. Most of the floor coverings of the building were destroyed, and those that survived were damaged. The floors in the parodoi were preserved with their marble coverings. However, the top cover of the parodoi had surface and fragment losses, and the marbles were shifted. The foundation of the cavea was covered in soil, vegetation occurred, and the stones were dispersed. In general, surface contamination can be found on the building walls. Some areas are covered with lichen, and these biological formations caused the loss of building materials.

During the excavations, temporary repairs were made in a short time to keep the building alive. However, because of age and climatic conditions, the degree of damages, such as joint loss, surface loss, vegetation, and pitting, has increased. The cavea foundation and the stones on the stage are on the verge of collapsing. Immediate protection interventions must be made using the original building material and appropriate construction technique. The odeon structures from the Hellenistic period are a unique type of structure. It is inevitable to ensure the sustainability of the Aizanoi odeon, of which only a part of the original structure has survived. 


\section{Giriş}

Grekçe olan Odeion kelimesi Latince kökenli Odeum teriminden gelmektedir ve şarkı anlamına gelen ode kelimesinden türetilmiştir. ${ }^{1} \mathrm{Bu}$ yapılar konserlerin, müzikallerin düzenlendiği üstü örtülü, küçük tiyatro benzeri yapılardır. ${ }^{2}$ Plan şemaları ve kapalı mekân olmaları sebebiyle "bouleuterion" (meclis binası) yapılarına benzemektedirler. Bu yapılar tiyatro ve stadionlar ${ }^{3}$ gibi halkın kullanımına açık olmayıp daha üst sınıfa ait özel yapılardır. ${ }^{4}$ Roma dönemi tiyatroları, yarım dairesel planlıdır ve genellikle doğal arazi eğimine oturtulmuş izleyici bölümüyle, alçak bir sahne bölümünden oluşmaktadır. ${ }^{5}$ Romalılar amfitiyatrolar inşa ederlerken, Yunanlılar imparatorluğun uzak bölgelerinde bile müzik holleri ya da oditoryumlar inşa etmişlerdir. ${ }^{6}$

Odeion yapıları, tiyatrolardaki gibi oturma sıraları (cavea), oyunun sergilendiği veya korunun yer aldığı yarım dairesel orkestra kısmı (orchestra), sahne (skene) ve sahne arkasından oluşmaktadır. Bu yapılar, tiyatrolara göre daha küçüktür ve kapalı olarak tasarlandıkları için Latincede çatılı tiyatro anlamına gelen "theatrum tectum", Grekçede ise "theatron hyporphion" sözcükleri ile adlandırılmaktadır. ${ }^{7}$ Odeion yapıları birçok tiyatro gibi gladyatör ve hayvan dövüşleri için arenaya ya da su balesinin sergilendiği bir mekâna da dönüştürülebilmiştir. ${ }^{8}$

Bu makalede Kütahya'nın Çavdarhisar ilçesinde yer alan Aizanoi antik kentinde yer alan Odeion yapısının yapım tekniği, yapıda kullanılan malzemelere ilişkin analiz sonuçları ve yapının hasar durumu incelenmiştir. Yapı 1998-2016 yıllarında gerçekleştirilen arkeolojik kazılar sırasında ortaya çıkarılmıştır. ${ }^{9}$ Sahne kısmı, orkestrası, paradoi (mermer geçit) ve caveası (oturma basamakları) temel tabanıyla kısmen günümüze ulaşmış olan yapının 2017 ve 2019 yıllarında hasar tespit çalışmaları gerçekleştirilmiştir. Yapıdan alınan harç ve taş örnekleri üzerinde laboratuvar ortamında karakterizasyon

1 Margarete Bieber, The History of The Greek and Roman Theater (Princeton, New Jersey: Princeton University Press, 1961), 220.

2 Edwin John Davis, Anadolu, 19. Yüzyılda Karya, Frigya, Likya ve Pisidya Antik Kentlerine Yapılan Bir Gezinin Öyküsü, çev. Funda Yılmaz (İstanbul: Arkeoloji ve Sanat Yayınları, 2006), 27; Bieber, The History of The Greek and Roman Theater, 220.

3 Antik Yunan'da stadion veya stadium kelimesi bir mesafe ölçümü, bir ayak yarışı veya seyircili yarışların yapıldığ 1 yer anlamına geliyordu. Mark Cartwright, "Stadium", World History Encyclopedia, erişim 2 Haziran 2021, https://www.worldhistory.org/stadium

4 Deniz Başar Öztürk, "Troas Bölgesi Odeion Yapıları” (Doktora Tezi, Çanakkale Onsekiz Mart Üniversitesi, 2006), 2.

5 Martin Thorpe, Roman Architecture (London: Bristol Classical Press, 1995), 56, 58.

6 Bieber, The History of The Greek and Roman Theater, 222.

7 Bieber, The History of The Greek and Roman Theater, 220.

8 Bieber, The History of The Greek and Roman Theater, 222.

9 Aizanoi kazılarına 1998 yılında Klaus Rheidt başkanlığında başlanmış, 2016 sezonu kazılarına ise Prof. Dr. Elif Özer başkanlık yapmıştır. Aizanoi Kazı ve Araştırmaları için Kültür ve Turizm Bakanlığı, Kültür Varlıkları ve Müzeler Genel Müdürlüğü tarafindan yürütülmüştür. Elif Özer, "Aizanoi 2016 Sezonu," 39. Kazı Sonuçları Toplantısı, 22-26 Mayıs 2017. c. 3. Bursa: T. C. Kültür ve Turizm Bakanlığı, Kültür Varlıkları ve Müzeler Genel Müdürlüğü, 2017, 207. 
analizleri yapılmış ve özgün malzemelerin özellikleri tayin edilmiştir. Yapı günümüzde çok hasarlı durumda olup oturma sıraları ve sahne bölümü kayba uğramıştır. Birçok yapı malzemesi de yitik durumda olan yapının hasar durumu belgelenmiştir.

\section{Aizanoi Antik Kenti Odeion Yapısı}

Aizanoi antik kenti Phrygia ${ }^{10}$ bölgesinde, günümüzde Kütahya ilinin güneybat1sındaki Çavdarhisar ilçesinde yer almaktadır (G. 1). Antik kentteki ilk yapılaşma Helenistik dönemde başlamış olup en parlak yıllarını İmparator Hadrianus zamanında yaşamıştır. ${ }^{11}$ Bizans döneminde de yaşamın devam ettiği kentte Zeus Tapınağ1, stadion-tiyatro kompleksi, macellum alanı, hamam, sütunlu cadde ve odeion yapıs1 bulunmaktadır (G. 2).

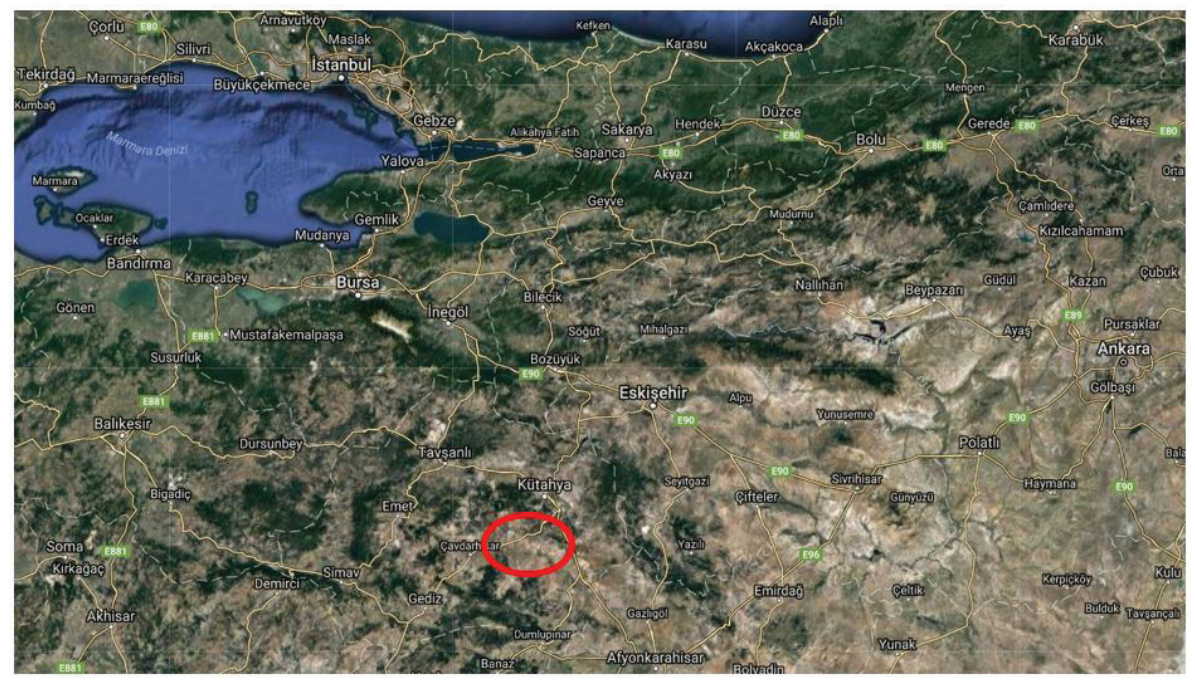

G. 1: Kütahya, Çavdarhisar ilçesinin konumu (https://www.google.com.tr/maps/place/Cavdarhisar)

Odeion yapısı Zeus Tapınağı'nın güneydoğusunda, Pankelas Çayı'nın (Kısıkboğaz Deresi) ise batısında, günümüzde ise Abdullah Özcan Caddesi'nin hemen kuzeybatısında yer almaktadır (G. 2, G. 3). Yapının duvarlarında yapılan kazı sonucunda bulunan tabakalarda yer alan Erken Roma dönemine ait mimari ve keramik buluntular, yapının MS 1. yüzyılın sonuna ya da 2. yüzyılın başında bouleuterion olarak inşa edildiğini, MS 4. yüzyılda yapılan onarımlar ve sahnenin eklenmesiyle odeiona dönüştürüldüğünü düşündürmektedir. ${ }^{12}$

10 Phrygia-Frigya, MÖ 12. yüzyıl ile MÖ 7. yüzyıllarda Orta Anadolu'da yer alan bir krallıktır. Krallığın çökmesinden sonra bu ad Küçük Asya'nın batı platosunda kapladığı genel coğrafi alana verilmiştir. Mark Cartwright, "Phrygia", World History Encyclopedia, erişim 2 Haziran 2021, https://www.worldhistory.org/phrygia.

11 Elif Özer ve Hatice Korkmaz, "Tarihsel Süreçte Aizanoi Kentindeki Dört Yapıda Tahrip ve Koruma,” Pamukkale Üniversitesi Sosyal Bilimler Enstitüsü Dergisi 18 (2014), 11.

12 Klaus Rheidt, “Dıe Ausgrabungen In Aizanoi 2001; Aizanoi 2001 Yılı Kazı Ve Onarım Çalışmaları” 24. Kazı 
Yapıdaki arkeolojik kazı çalışmaları 1998 yılında başlamışıır. ${ }^{13} 2001$ yılındaki kazılarda yapının büyük bir kısmı ortaya çıkarılmıştır. Caveanın alt kısmında yer alan in-situ (yerinde) hâlindeki iki basamak Kültür Bakanlığı'nın yürüttüğü 1998-1999 yılları kazılarında açığa çıkarılan mermer geçit (paradoi) ile birleşmektedir ve aynı dönemde inşa edildiğini göstermektedir. Paradoide yer alan büyük taşlar başka bir yapıdan hatta bir tiyatronun basamak taşlarından getirilerek kullanılmış olmalıdır. Geç Antik dönem devşirme malzeme kullanımının kökeni MS 2. yüzyıllarda başlamaktadır. ${ }^{14}$ Odeion yapısı ve orkestra, 3 kapı ile dor sütunlu tapınak avlusuna açılmaktadır (G. 2, G. 3). Kazı çalışmaları sırasında kapı eşiklerinin altında başka bir döneme ait döşeme bulunması, kapıların ikinci yapı evresinde onarım gördüğünü göstermektedir. ${ }^{15}$ Döşemedeki devşirme elemanların erken dönem kemerine ait olduğu, çalışma sırasında birçok sikke bulunmasından dolayı da bu müdahalenin MS 3. yüzyılda yapıldığını göstermektedir. Bu dönemde orkestra tabanının kare mermer levhalarla döşendiği ve güneydoğu kısmında mermer levhalarla kaplı taş duvarla sınırlandırıldığı görülmüştür. Orkestra zemininde güneydoğuya doğru bir eğim, bir su kanalı ve su çıkışı bulunmaktadır. Kapalı olarak tasarlanmış olan yapıda böyle bir mimari düzenlemenin olması, mekânın orkestrasının su oyunları için su ile doldurulduğunu düşündürmektedir.

Kapı ile orkestra kısmındaki duvar arasında yer alan harçlı taban tuğlası kalıntıları, sahnenin tuğla döşemeye sahip olduğunu açıklamaktadır. Antik dönem yapısı olan odeionun yer aldığı alanda Orta Bizans dönemine tarihlendirilen kireç çukuru kalıntıları ve mermer kırıkları bulunmuştur. Bu veriler yapının bu dönemde sökülerek kireç elde etmek amacıyla yakıldığını göstermektedir. ${ }^{16}$

Tapınağın güneybatısında yer alan yapının arka duvarının tapınak avlusuyla bağlanabilmesi için teraslandığ ve bu düzenlemenin avlunun inşaatına tarihlendirilen geç Traianus döneminde (MS 98-117) yapıldığını düşündürmektedir. 2001 yılı kazılarında odeionun yan basamakları tamamlanarak cavea bölümüne geçiş sağlanmış ve yapı ziyarete açılmıştır. ${ }^{17} 2016$ yılı kazılarında daha önce büyük bir bölümü açığa çıkarılmış olan yapının caveasının batısındaki kazı alanı 1,5 m genişletilerek dağınık duran moloz taşlar ve çevre sınırları belirlenmiş, taşların üstü temizlenmiştir. Güney paradoide de yapı sınırını belirlemek amacıyla 1,5 m genişliğindeki alanda kazı yapılmıştır. Bu çalışmalar sırasında güneybatı-kuzeydoğu genişliğinin 20,30 m olduğu tespit edilmiştir (G. 4). ${ }^{18}$

Sonuçları Toplantısı, 27-31 Mayıs 2002 (Ankara: T. C. Kültür Bakanlığı Yayınları, 2002), 2: 319.

13 Klaus Rheidt, "Die Ausgrabungen in Aizanoi 2002; Aizanoi 2002 Yılı Çalışmaları," 25. Kazı Sonuçları Toplantısı, 26-31 Mayıs 2002 (Ankara: T. C. Kültür Bakanlığı Yayınları, 2003), 1: 131.

14 Elizabeth Riorden,"A Hadrianic Theater at Ilion (Troy): a Paradigm Shift for Roman Building Practice and Its Aesthetic Aftermat," Proceedings of the Second International Congress on Construction History, 3. (USA: Cambridge University, 2006), 2648.

15 Rheidt, "Die Ausgrabungen In Aizanoi 2001; Aizanoi 2001 Yılı Kazı Ve Onarım Çalışmaları,” 319.

16 Rheidt, "Die Ausgrabungen In Aizanoi 2001; Aizanoi 2001 Yılı Kazı ve Onarım Çalışmaları," 319.

17 Rheidt, "Die Ausgrabungen in Aizanoi 2002; Aizanoi 2002 Yılı Çalışmaları," 131.

18 Elif Özer, "Aizanoi 2016 Sezonu," 208. 


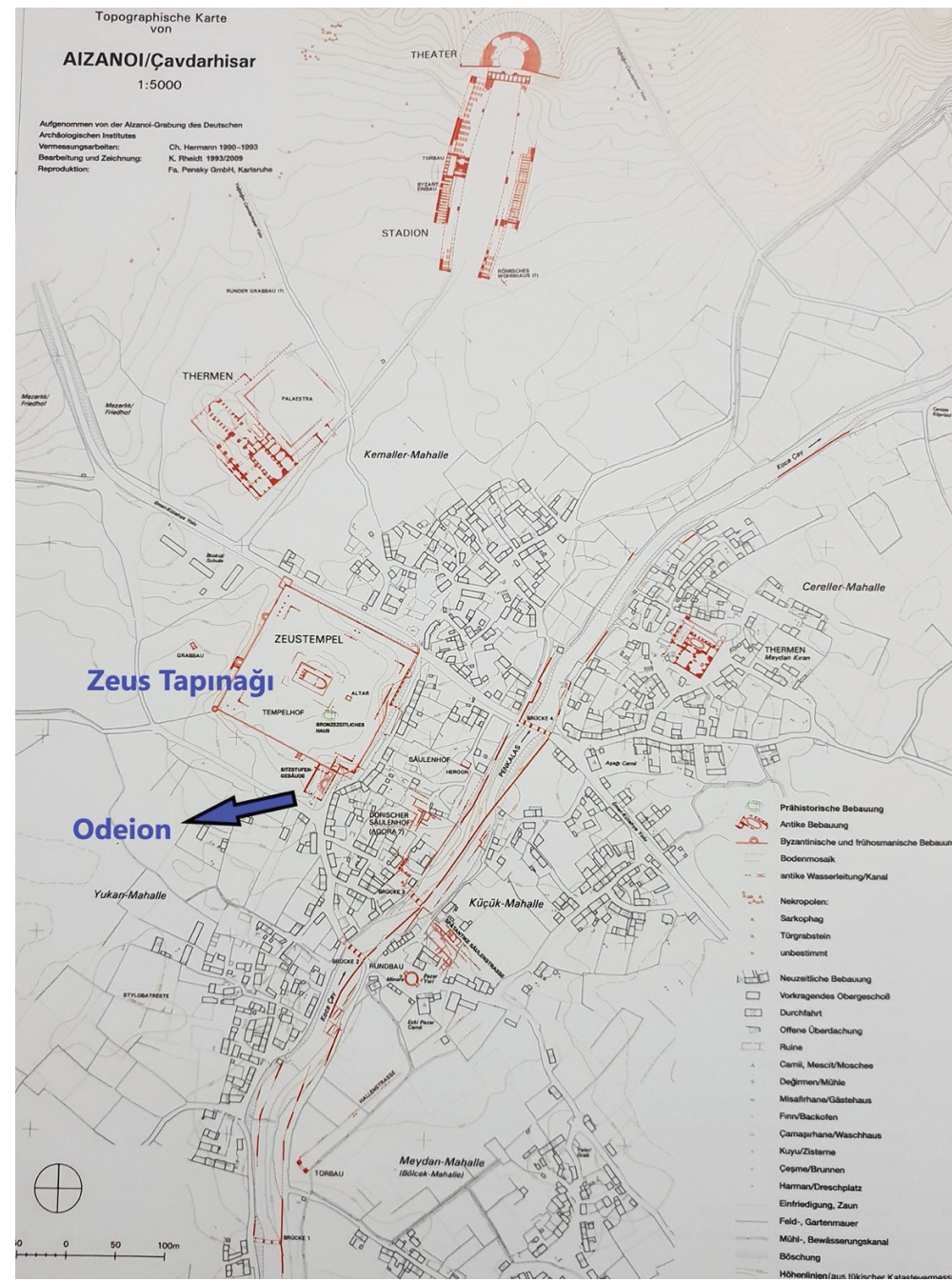

G. 2: Aizanoi, Çavdarhisar 2009 yılı 1/5000 imar planı ve Aizanoi antik kenti yapıları (Klaus Rheidt, Aizanoi und Anatolien. Neue Entdeckungen zur Geschichte und Archäologie im Hochland des westlichen Kleinasien, 6)

2016 yılı kazılarında sınırları belirlenerek tamamlanan arkeolojik kazılarda yapının orkestra kısmı, tiyatro oturma alanının ilk 2 sirası in-situ olarak, 3. ve 4. sırasının izleri, caveaya yükselen basamaklar ile kuzey ve güney paradoinin duvarları açığa çıkmışırı (G. 4). Oturma basamaklarının genişlikleri yaklaşık 50-55 cm olup, rıht ve oturma sıralarından meydana gelmektedir. Oturma sıralarının rıhtları caveaya çıkan basamakları da oluşturmaktadır. 


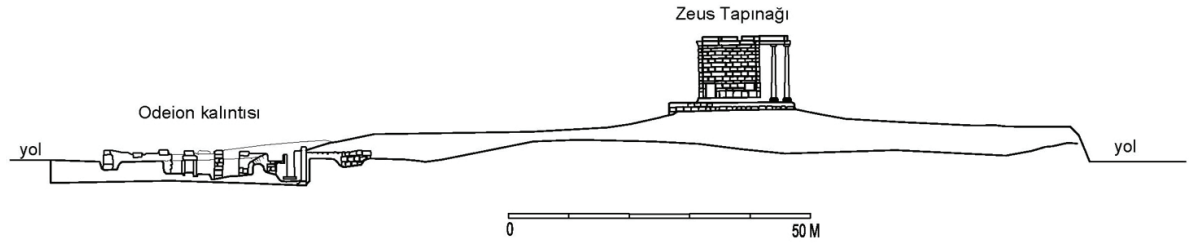

G. 3: Aizanoi antik kenti odeion yapı kalıntısının Zeus tapınağına göre konumu (Klaus Rheidt, Aizanoi und Anatolien. Neue Entdeckungen zur Geschichte und Archäologie im Hochland des westlichen Kleinasien, 19'dan referans alınarak yazarlar tarafindan düzenlenmiştir.)

Yarım dairesel formlu orkestranın çevresine yerleşmiş cavea sıralarının 4. sıradan itibaren olan taşları günümüze ulaşmamıştır ancak yapının kuzeyindeki sütunlu avluya kadar olan kısmında oturma sıralarının altındaki moloz dolgu temel tabanının sınırları görülmektedir (G. 4). Yapının orkestra kısmı yaklaşık 2.60 m yarıçapındadır. Orkestra zemininde, mermer döşeme kalıntıları ile kireç esaslı harç yatağı bulunmaktadır (G. 5).

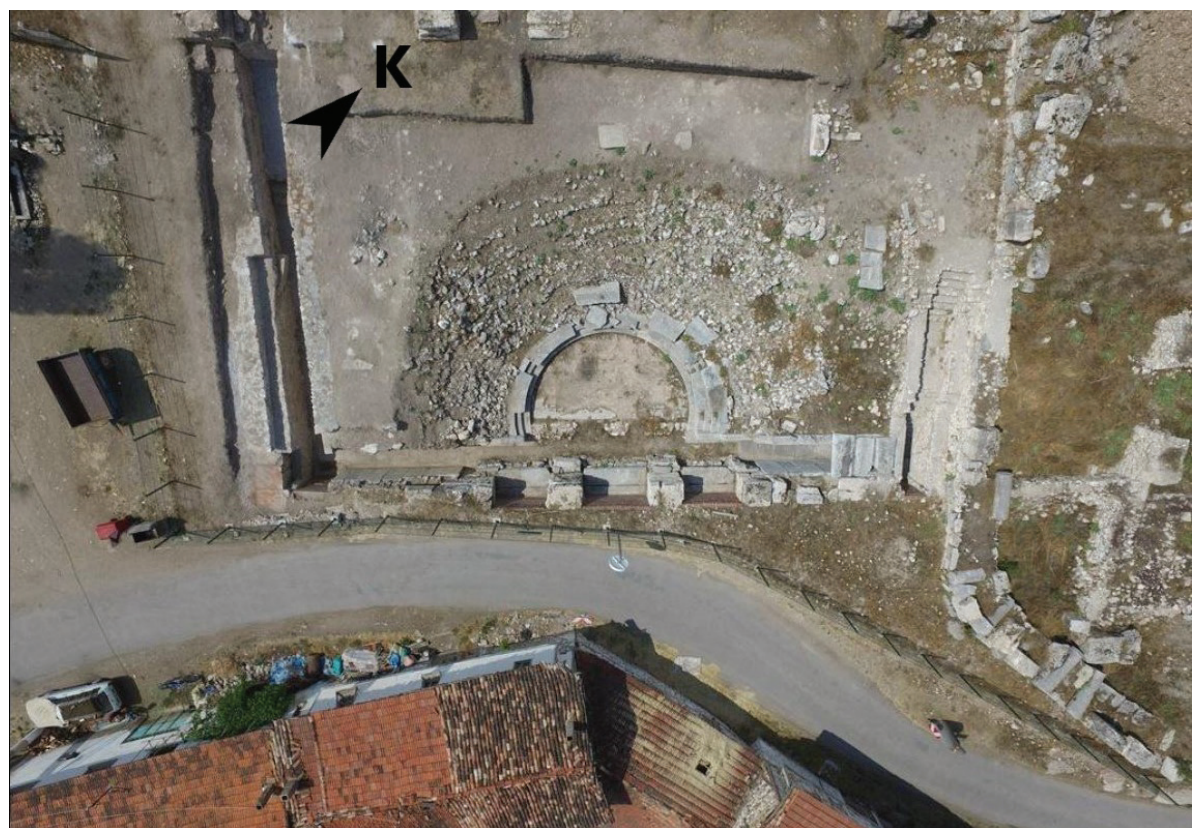

G. 4: Odeion yapısı 2016 y1lı kazıları sonrasındaki durumu (Elif Özer, “Aizanoi 2016 Sezonu,” 219)

Zeminindeki mermer kaplama, koyu gri renkli, yer yer beyaz damarları olan, sert ve sağlam yapılıdır. Cavea kısmını paradoi ile ayıran duvar, kesme taş büyük bloklarla inşa edilmiştir. Kuzeydoğudaki paradoinin büyük bir kısmı ayaktadır, güneydoğudakinin ise ancak duvarları ile sınırları takip edilebilmektedir (G. 4). Yaklaşık $70 \mathrm{~cm}$ ge- 
nişliğinde, $6.60 \mathrm{~m}$ uzunluğunda olan kuzeydoğu paradoinin zemin döşemeleri, cavea ile arasındaki duvar, sahne duvarı ve bir kısım üst örtüsü günümüze ulaşabilmiştir. Bu mermer geçidin üzerindeki mermer taşlarla yapılmış örtüden 3 adeti mevcuttur ve üst kısımlarında kenarları iç bükey profilli devşirme taşlar olduğu görülmektedir (G. 6b). Bu taşların bir tiyatro yapısının basamak taşları olabileceği düşünülmüştür. ${ }^{19}$ Paradoi, yekpare mermer lentolu kapı geçişi ile kuzeydoğudaki koridora açılmaktadır (G. 4, G. 6b). Bu koridorun üst örtüsü mevcut olmayıp her iki kenarındaki duvarları sıralı moloz taş örgülüdür. Yaklaşık 1.00 m genişliğindeki koridor, moloz taş basamaklarla tapınak avlusuna açılmaktadır (G. 4). Duvarların üzerinde ve basamaklarda sağlamlaştırma amaçlı çimento esaslı onarımlar yapılmıştır.

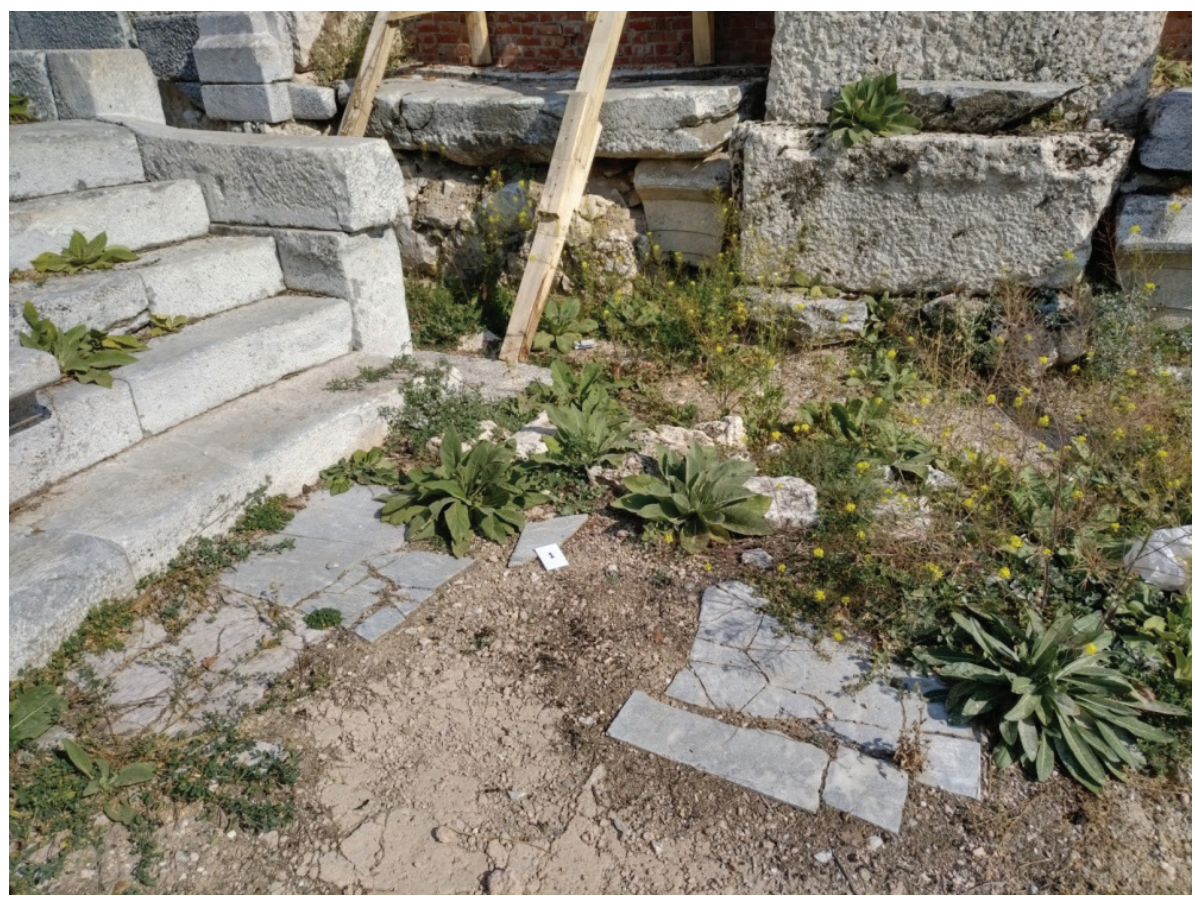

G. 5: Yapının orkestra döşeme kalıntısı ile kireç esaslı harç yatağı (Acun Özgünler, 2017)

Geçidin sahne duvarıyla birlikte devam eden kısmı kuzeydeki gibi mermer kaplıdır ve profilli mermer kapı sövesi ile sonlanmaktadır. Bu paradoiden güneydeki koridora ulaşılmaktadır (G. 4). Kuzeydeki geçit gibi duvarları, kazı çalışmaları sırasında yapılmış olan sağlamlaştırmalar ile kısmen günümüze ulaşabilmiştir. Kuzeydeki koridorun simetriği olarak avluya geçişi sağlayan bu koridorun ancak moloz taş ile örülmüş 3 basamağı mevcuttur. Zemindeki dolgu malzemesinin daha fazla kayba uğramaması için kazı ekibi tarafından üzeri kırma taş dolgu ile kapatılmıştır.

19 Rheidt, “Die Ausgrabungen In Aizanoi 2001; Aizanoi 2001 Yıılı Kazı Ve Onarım Çalışmaları,” 319. 

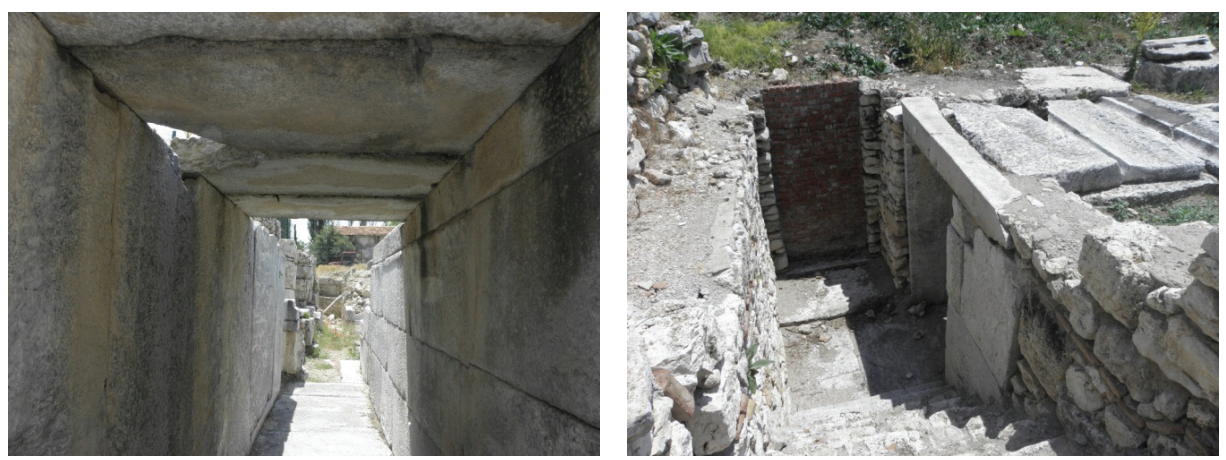

G. 6: Kuzeydoğu paradoi a) iç kısmı b) üst örtüsü, girişi ve kap1 sövesi (Acun Özgünler, 2017)

Sahne duvarının arka kısmı kayba uğramıştır. Günümüzde Abdullah Özcan Caddesi sahne duvarının üzerine oturmaktadır (G. 7). Paradoi duvarlarıyla devam eden sahne 3 bölümlü olarak tasarlanmıştır. Özgün hâlinde mermer kaplamalı ve bezemeli olduğu düşünülen sahnenin moloz taş kaidesi ve üzerindeki mermer döşemesi sahnenin orkestraya göre konumunu gösteren izlerdir. Döşeme üzerinden itibaren 3 sahne nişi ancak taşıyıcı duvarları ile algılanabilmektedir. Nişlerin genişlikleri yaklaşık 1.001.10 m'dir. Arka duvarlarının nerede başladığını gösteren izler mevcut olmadığ 1 için derinlikleri tayin edilememiştir. Nişleri birbirinden ayıran duvarların ancak 3 sıras1 mevcuttur ve büyük blok taşlarla yapılmıştır (G. 7). Sahne, hemen arkasına inşa edilmiş yol sebebiyle büyük oranda kayba uğramış ve bu kısım 2016 yılındaki kazı çalışmaları sırasında tuğla duvarlarla takviye edilmiştir. ${ }^{20}$ 


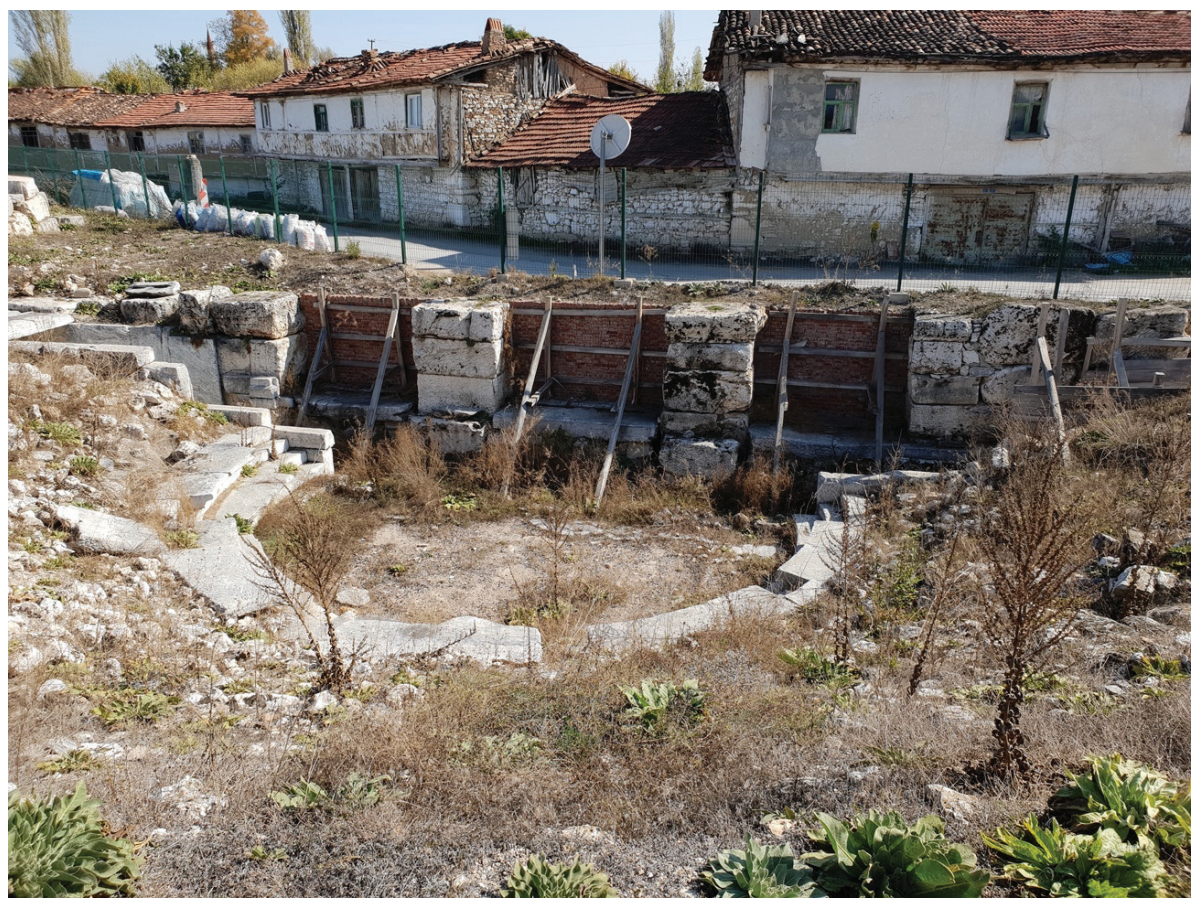

G. 7: Yapının ve sahne kısmının cadde ile ilişkisi (Kahraman, 2019).

Tamamlanan arkeolojik kazı sınırlarına ve kazı ekibinin 2016 yılı hava fotoğrafina göre (G. 4) yapının yaklaşık $8.70 \mathrm{~m}$ yarıçapındaki yarım dairesel formlu bir iç mekândan ve dor sütunlu avludan geçişleri sağlayan koridorlarla birlikte dikdörtgen formdaki bir dış kabuktan oluştuğu düşünülmektedir.

\section{Yapım Tekniği ve Malzeme Özellikleri}

Yapı büyük oranda kayba uğrayarak günümüze ulaşabilmiştir. Yapının caveasının moloz taş temel tabanı, mermer basamak taşları ve ön kenarları pahlı oturma sıralarından oluştuğu görülmektedir. Orkestra kısmı yarım dairesel formlu ve mevcuttaki döşeme kalıntılarından mermer bir zemine sahip olduğu tayin edilmektedir. Yapıdan 5 adet taş, 5 adet harç ve 1 adet yapay taş örneği alınmıştır (Tablo 1). Harç örneklerinin bağlayıcı ve agrega türlerini, oranlarını belirlemeye yönelik olarak görsel analiz, fiziksel özellik deneyleri, kızdırma kaybı analizi ile asit kaybı analizi sonunda kalan agregaların elek analizleri yapılmıştır. Taş örnekler de ise, görsel analiz ile fiziksel, kimyasal ve mekanik özellik deneyleri yapılmıştır. ${ }^{21}$ Örnekler üzerinde yapılmış deneysel analiz sonuçlarına göre hazırlanmış olan Tablo 1 malzeme özelliklerini özet şeklinde göstermektedir.

21 Yapı malzemelerine ilişkin malzeme analizleri Prof. Dr. Seden Acun Özgünler tarafından İstanbul Teknik Üniversitesi Döner Sermaye Projesi olarak yapılmıştır. Seden Acun Özgünler, "Kütahya Çavdarhisar Aizanoi Odeon Yapısı Hakkında Malzeme Raporu” (İstanbul: 2017). 
Tablo 1: Yapıdan alınan malzeme örneklerinin yeri ve özellikleri (Acun Özgünler ve Kahraman, 2021)

\begin{tabular}{|c|c|c|c|}
\hline Örnek No & Tanımı & Alınma Yeri & Deney sonuçlarına göre malzeme özellikleri \\
\hline Örnek-1 & Taş & Orchestra zemini & $\begin{array}{l}\text { Koyu gri renkli, yer yer beyaz damarları olan, sert ve } \\
\text { sağlam yapılı bir mermer örneğidir. }\end{array}$ \\
\hline Örnek-2 & Taş & $\begin{array}{l}\text { Cavea-Krepis } \\
\text { basamağ } 1\end{array}$ & $\begin{array}{l}\text { Koyu gri renkli, yer yer beyaz damarları olan, sert ve } \\
\text { sağlam yapılı bir mermer örneğidir. } 1 \text { numaralı örneğe } \\
\text { benzemektedir. }\end{array}$ \\
\hline Örnek-3 & $\begin{array}{l}\text { Yapay } \\
\text { taş }\end{array}$ & Paradoi/lento bloğu & Çimento bağlayıcılı yapay taş, onarım müdahalesi. \\
\hline Örnek-4 & Harç & Duvar yastık harc1 & $\begin{array}{l}\text { Bej renkli, bağlayıcı olarak çimento ile kireç bulunan, } \\
\text { agrega olarak çoğu } 4 \mathrm{~mm} \text { altı dere kumu görülen, çok } \\
\text { sağlam yapıda bir melez harç örneğidir. }\end{array}$ \\
\hline Örnek-5 & Harç & $\begin{array}{l}\text { Duvar örgü onarımı } \\
\text { derz harcı }\end{array}$ & $\begin{array}{l}\text { Bej renkli, bağlayıcı olarak çimento ile kireç bulunan, } \\
\text { agrega olarak } 8 \mathrm{~mm} \text { altı dere çakılı+kumu ile birlikte } \\
\text { yaklaşı } \% 10 \text { oranında iri tuğla kırıkları da görülen, } \\
\text { sağlam yapıda bir melez harç örneğidir. }\end{array}$ \\
\hline Örnek-6 & Harç & $\begin{array}{l}\text { Basamak onarımı } \\
\text { derz harcı }\end{array}$ & $\begin{array}{l}\text { Bej renkli, bağlayıcı olarak çimento ile kireç bulunan, } \\
\text { agrega olarak çoğu } 4 \text { mm altı dere kumu görülen, sağlam } \\
\text { yapıda bir melez harç örneğidir. } 4 \text { no.lu örneğe benze- } \\
\text { mekle birlikte aşırı derecede bozunmuş durumdadır. }\end{array}$ \\
\hline Örnek-7 & Harç & Duvar derz harcı & $\begin{array}{l}\text { Açık gri renkli, bağlayıcı olarak çimento ile kireç } \\
\text { bulunan, agrega olarak } 8 \mathrm{~mm} \text { altı dere çakıııı ile kumu } \\
\text { görülen, sağlam yapıda bir melez harç örneğidir. }\end{array}$ \\
\hline Örnek-8 & Taş & $\begin{array}{l}\text { Paradoi duvarı-iç } \\
\text { cidar }\end{array}$ & $\begin{array}{l}\text { Açık krem renkli, mikritik dokulu, sağlam yapılı bir } \\
\text { yoğun kalker örneğidir. }\end{array}$ \\
\hline Örnek-9 & Taş & Paradoi döşemesi & $\begin{array}{l}\text { Beyaz renkli, yer yer siyah kalın damarları olan, sert ve } \\
\text { sağlam yapılı bir mermer örneğidir. }\end{array}$ \\
\hline Örnek-10 & Harç & Geç dönem duvarı & $\begin{array}{l}\text { Geç dönem duvar kalıntısından alınan örnek, pembe } \\
\text { renkli, esas bağlayıcısı kireç olan, agrega olarak yoğun } \\
\text { iri tuğla kırıkları (10-15mm) ile tuğla tozu bulunan, } \\
\text { ayrıca az miktarda kum da görülen, orta sağlam yapıda } \\
\text { bir horasan harcı örneğidir. }\end{array}$ \\
\hline Örnek-11 & Taş & Sahne duvarı-iç cidar & $\begin{array}{l}\text { Açık krem renkli, mikritik dokulu, sağlam yapılı bir } \\
\text { yoğun kalker örneğidir. }\end{array}$ \\
\hline
\end{tabular}

Taş örneklerinde fiziksel özellik deneyleri olarak; atmosfer basıncı altında daldırma yöntemi ile su emme (kütlece/hacimce), birim hacim kütle, özgül kütle, deneyleri yapılmış boşluk-doluluk oranları bulunmuştur. Deneyler, taş örneklerinden hazırlanan numuneler üzerinde, “TS EN 771-1, TS EN 772-4 Kagir Birimler ve TS 699/2009 Doğal Taşlar" standartlarına uygun olarak yapılmış ve sonuçları hesaplanmıştır. Mekanik özelliklerin tayini için ise; TS 699 standardına uygun olarak; eğilmede çekme dayanımı ve eğilmede çekme deneyinde kırılan parçalarda basınç dayanımı, ultrases hızı ve dinamik elastisite modülü deneyleri yapılmıştır. Bu deneyler, 40x40x160 mm boyutlu prizmatik, önekler üzerinde Form Test Seidner marka 10KN eğilme ve 200 KN (20 ton) basınç kapasiteli test cihazı yardımı ile yapılmıştır. Deney sonuçları taş örneklerinden hazırlanan 3 'er numunenin deney sonuçlarının aritmetik ortalaması alınarak Tablo 2'de verilmiştir. 
Tablo 2: Taş örnekleri üzerinde yapılmış olan deneysel çalışmaların sonuçlarına ilişkin özet tablo (Acun Özgünler ve Kahraman, 2021)

\begin{tabular}{|l|c|c|c|c|c|}
\hline Örnek & $\mathbf{C a C O}_{3}$ Miktarı (\%) & $\begin{array}{c}\text { Birim Hacim } \\
\left.\text { Kütle (gr/cm }{ }^{3}\right)\end{array}$ & Porozite (\%) & $\begin{array}{c}\text { Ortalama } \\
\text { Basıç } \\
\text { Dayanımı } \\
\text { (MPa) }\end{array}$ & $\begin{array}{c}\text { Ĕgilmede } \\
\text { Çekme } \\
\text { Dayanımı } \\
\text { (N/mm } \mathbf{2}\end{array}$ \\
\hline Örnek-1 & 95 & 2,65 & 3,6 & & \\
\hline Örnek-2 & 95 & 2,67 & 3,3 & 80 & 29 \\
\hline Örnek-8 & 94 & 2,57 & 5,2 & 77 & 21 \\
\hline Örnek-9 & 90 & 2,67 & 2,5 & 47 & 16 \\
\hline Örnek-11 & 72 & 2,58 & 3,4 & 75 & 20 \\
\hline
\end{tabular}

Orkestra zemini, cavea basamağından alınan örneklerin koyu gri renkli, beyaz damarlı ve sağlam yapılı mermer oldukları, fiziksel özellik ve kızdırma kaybı analizi sonuçlarındaki değerlerinin de benzer olduğu görülmüştür. Paradoi zemininden alınan 9 numaralı döşeme örneği; beyaz renkli, siyah kalın damarlı ve sağlam yapıda bir mermerdir (Tablo 1). Laboratuvar ortamında yapılan deneysel çalışmalarda, paradoi zemininden alınan mermerin cavea ve orkestra zemininden alınan 1 ve 2 numaralı mermer örneklerinden farklı özellikte, porozitesinin (boşluk oranının) ve basınç dayanımının bu mermerlere göre daha düşük olduğu tespit edilmiştir (Tablo 2). Beyaz ve gri damarlı mermerler karbonat oranı yüksek metamorfik bir kayaçtır. ${ }^{22}$

Paradoi duvarlarının cavea ile birleştiği kısmın taşıyıcı mermer bloklardan; sahne duvarı ile birleştiği kısmın ise moloz taş taşıyıcı duvar üzerine mermer kaplama şeklinde yapıldığ 1 görülmektedir (G. 6b). Cavea, paradoi duvarları ve oturma basamakları derzsiz olarak yapılmış, taşlar demir kenetler ile bağlanmıştır (G. 8, G. 9). Bu dönem yapılarında mermerler büyük bloklar şeklinde uygulanmaktadırlar ve homojen yapılı olan bu elemanlar genellikle derzsiz olarak döşenmişlerdir. ${ }^{23}$

Paradoinin taşıyıcı moloz taş örgüsünden alınmış olan örnek 8 ile sahne önü duvarının taşıyıcı duvarından alınmış 10 numaralı taş örneklerinin analiz sonuçları yoğun kalker taşı olduklarını göstermektedirler. Her iki taşın da birim hacim kütleleri 2,57- 2,58 gr/ $\mathrm{cm}^{3}$ 'tür. Bu örneklerden 40x40x160 mm boyutlarında hazırlanmış olan numuneler üzerinden yapılmış olan mekanik testler, örneklerin ortalama basınç dayanımlarının 75-77 MPa, eğilmede çekme dayanımlarının ise 20-21 N/mm² olduğunu göstermektedir (Tablo 2).

22 Metamorfik ya da başkalaşım kayacı tortul ya da magmatik kayaçların çeşitli etkilerle değişikliğe uğraması sonucu oluşur. Mermer, metamorfik bir kayaçtır. Andy Barker, Introduction to Metamorphic Textures and Microstructures (United Kingdom; Stanley Thomes Ltd, 1998), 3-5.

23 John Ashurst ve Francis G. Dimes, Conservation of Building \& Decorative Stone (Oxford: ButterworthHeinemann, 1998), 30. 
Harç örneklerinin fiziksel özelliklerini belirlemek üzere, TS 699 standardına uygun olarak atmosfer basıncında su emme, birim hacim kütle ve özgül kütle deneyleri yapılmıştır. Asit kaybı analizinde, \%14 oranında seyreltilmiş $\mathrm{HCl}$ türü asit kullanılmıştır. Asit kaybı analizi sonrasında kalan agregalar üzerinde elek analizi yapılarak kullanılmış olan agrega boyutları tayin edilmiştir. Kızdırma kaybı analizi, toz hâline getirilen örneklerin sırasıyla $550^{\circ} \mathrm{C}$ ve $1050{ }^{\circ} \mathrm{C}$ 'lerde kül firınında tutulmuştur. $\mathrm{Bu}$ analiz sonuçları Tablo 3’te gösterilmiştir.

Tablo 3: Harç örnekleri üzerinde yapılmış olan deneysel çalışmaların sonuçlarına ilişkin özet tablo (Acun Özgünler ve Kahraman, 2021)

\begin{tabular}{|c|c|c|c|c|c|}
\hline Örnek & $\begin{array}{c}\text { Asit } \\
\text { Kaybı } \\
(\%) \\
\end{array}$ & $\begin{array}{c}\mathrm{CaCO}_{3} \\
\text { Miktarı } \\
(\%) \\
\end{array}$ & $\begin{array}{c}\mathrm{CO}_{2} / \mathrm{H}_{2} \mathrm{O} \\
\text { Orani* } \\
(\%) \\
\end{array}$ & $\begin{array}{l}\text { Bağlayıcı/ Agrega } \\
\text { Oranı (Ağırlıkça) }\end{array}$ & $\begin{array}{c}\text { Porozite } \\
\text { (\%) }\end{array}$ \\
\hline Örnek-4 & 22 & 20 & 4,1 & $1 / 3,5$ & 25 \\
\hline Örnek-5 & 18 & 18 & 4,4 & $1 / 3,5$ & 29 \\
\hline Örnek-6 & 20 & 16 & 5,1 & $1 / 3,5$ & 35 \\
\hline Örnek-7 & 18 & 18 & 4,7 & $1 / 3,5$ & 30 \\
\hline Örnek-10 & 39 & 34 & 4,7 & $1 / 2$ & 49 \\
\hline Örnek-3 & 75 & 76 & 5,7 & Yapay taş & 26 \\
\hline
\end{tabular}

Yapının farklı bölümlerinden alınmış olan yatak harc1, derz harcı ve basamak harc1 örneklerinin mikroskobik incelemeleri ve kimyasal analiz sonuçlarına göre bej renkli kireç ve çimento bağlayıcılı melez harç örnekleri oldukları görülmüştür (Tablo 1). $\mathrm{CaCO}_{3}$ miktarı \%18-20 aralığında olan harçların bağlayıcı/agrega oranı ise 1/3,5'tur (Tablo 3). Asit kaybı analizi sonrasında kalan agrega kısmında yapılmış olan elek analizi sonucuna göre 8-4 mm ve altı dere kumu agregaya sahip olduğu tayin edilmiştir. Geç dönem duvarından alınmış olan örnek 10'un diğer harçlardan farklı olarak bağlayıcı/ agrega oranı $1 / 2$ 'dir ve $10-15 \mathrm{~mm}$ aralığında iri tuğla kırıkları yoğun bir agrega kısmına sahip pembe renkli kireç harcıdır.

Paradoi geçişlerinin zeminleri kireç harç yatağı üzerine mermer kaplama şeklinde yapılmıştır (G. 6a). Güneydoğudaki paradoinin üstü devşirme mermer elemanlarla örtülmüştür (G. 6b). Bu kısmın kapı geçişi lentosu ile birlikte algılanırken, kapı sövesi mevcut değildir (G. 6b). Güneybatıdaki paradoinin bir kenarında kısmen mevcut olan sövenin mermer ve profilli olduğu görülmektedir. Köşe taşları özenli bir şekilde yapılmıştır. Güneybatıdaki paradoinin cavea kısmındaki duvar örgüsündeki taşların birbirine kenetlenerek yapıldığı dikkat çekmektedir (G. 9). Paradoiye açılan yan koridor duvarları köşe taşlarından sonra sıralı moloz taş örgü olarak devam etmektedir (G. 8). Bu örgülerin kesme taş duvar örgüsü ile aynı seviyede olması, önünde bir kaplama olmadığını düşündürmektedir. Paradoi kesme taş bloklar ile düzenlenmiş olup yan koridorlar opus-vittatum ${ }^{24}$ tekniğinde yapılmış olabilir. 
Yapının sahne kısmının mermer kaplamaları günümüze ulaşmamıştır ancak paradoi duvarlarındaki mermer kaplamalar ile devam ettiği düşünülmektedir. Orkestra zemininden yaklaşı $60 \mathrm{~cm}$ yüksekliğindeki mermer blokların altında moloz taş kaide kısmı yer almaktadır. Kaidedeki örgüde antik döneme ait devşirme malzemelerin dolgu amaçla kullanıldığı görülmüştür.
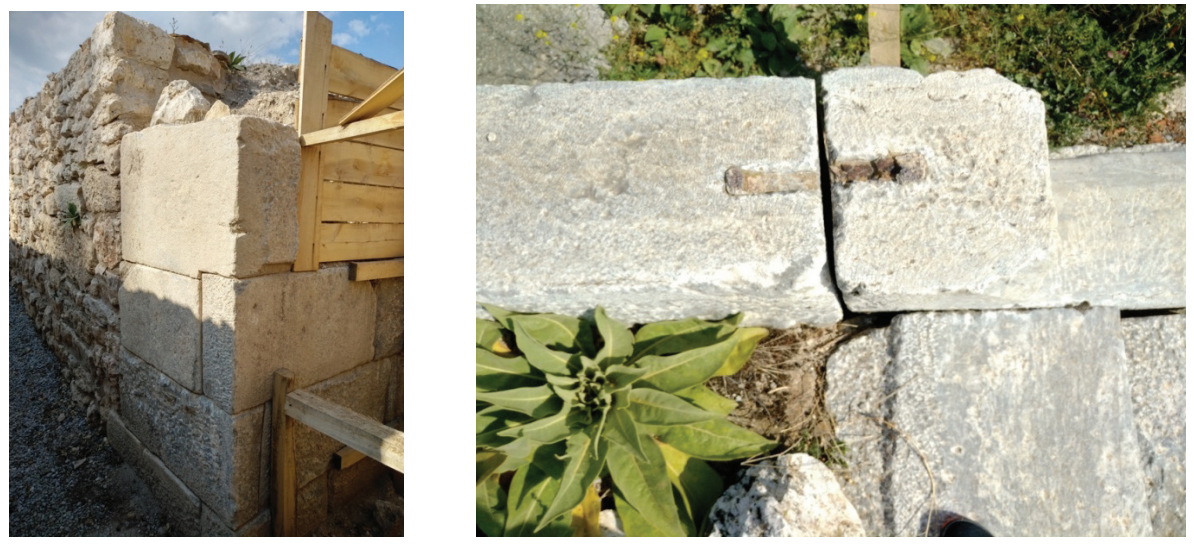

G. 8: Güneydoğu paradoisi köşe kısmı

G. 9: Kuzeydoğu paradoi duvarı (Acun Özgünler, 2017).

2001 yılı kazılarında sahne ile orkestra zemini arasında harçlı taban tuğlası kalıntıları bulunmuş ve bu verilerden hareketle döşemenin tuğla olduğu kanısına varılmıştır. ${ }^{25}$ Sahne zemininin üzerindeki taşıyıcı duvarlar geniş kesme kalker taş bloklardan oluşmaktadır (Tablo 1). Günümüzde bu taş blokların arasındaki tuğla ile yapılmış örgü takviye amaçlıdır. ${ }^{26}$ Arkasındaki yolun varlığından dolayı hasar görmüş olan sahne duvarını ayakta tutabilmek amacıyla arkeolojik çalışmalar sırasında koruma önlemi olarak uygulanmıştır.

Paradoi duvarı ile birleşen doğu ve batıdaki koridorlarının kaplama malzemesi ve zemin döşemesi günümüze ulaşmamıştır. Dor sütunlu avluya basamaklar ile çıkılan koridorlardan kuzeydekinin basamakları büyük ölçüde mevcuttur, güneydekiler de yine moloz taş örgülü olup ancak 3 basamağı bulunmaktadır. Bu geçişlerin duvarlardaki derz ve malzeme kayıplarından dolayı kazı çalışmaları sırasında birtakım sağlamlaştırma çalışmaları yapılmıştır. Kireç ve çimento esaslı bu onarımlarda duvardan düşen taşlar ve tuğlaların kullanılmış olduğu (G.10a, G.10b), duvar üstlerinin tesviye harcı ile düzeltildiği, güneydoğudaki koridorun basamaklarının çimento esaslı harç ile onarıldığı görülmüştür. Bu geçişlerde farklı dönemlerde onarımlar yapılmıştır, son onarımlar 2016 yılına tarihlendirilmektedir. Paradoi ve basamaklardaki onarım

and Francis Group, 1980), 273.

25 Rheidt, "Die Ausgrabungen In Aizanoi 2001; Aizanoi 2001 Yılı Kazı Ve Onarım Çalışmaları,” 319.

26 Özer, “Aizanoi 2016 Sezonu,” 209. 
harçlarının bej renkli olduğu görülmektedir. Bu harçlar çimento ve kireç esaslı olup içerisinde çoğunlukla dere çakılı ve \%10 oranında tuğla agrega bulunmaktadır. Sahne kısmında yapılan 2016 yılındaki dolgu niteliğindeki müdahalelerin ise açık gri renkli ve kireç-çimento esaslı melez harçla yapılmış olduğu tespit edilmiştir (Tablo 1, Tablo 3, G. 13).

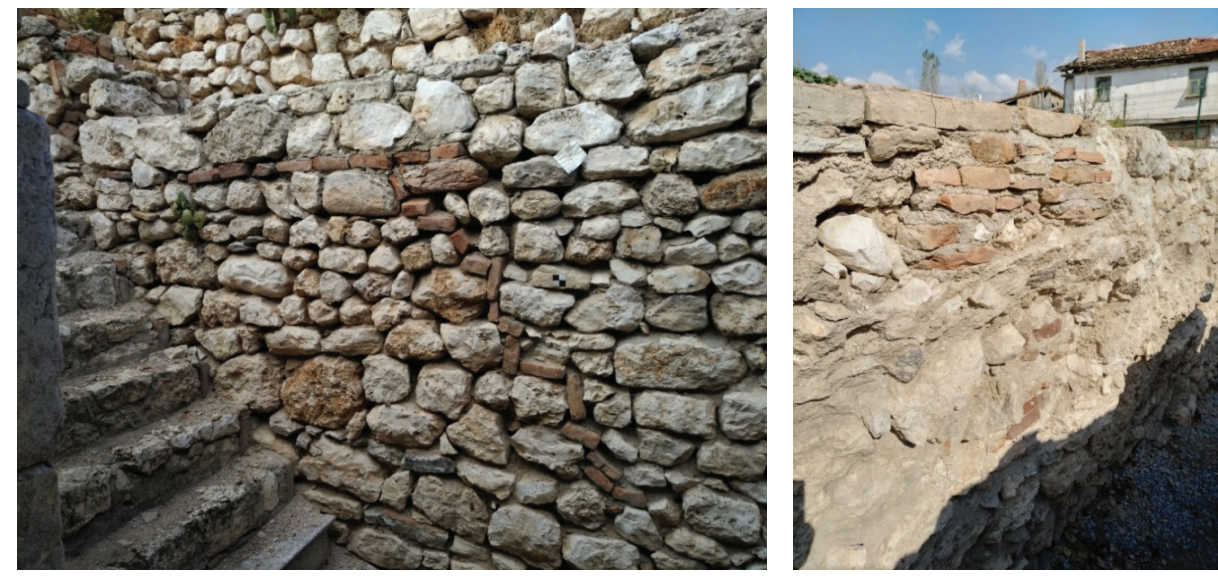

G. 10: 2016 yılında yapılan sağlamlaştırma müdahaleleri a) doğu koridoru b) batı koridoru (Acun Özgünler, 2017).

\section{Yapıya İlişkin Koruma Sorunları}

Kayba uğramış olan yapıların iklimsel koşullara açık durumda olması hasar durumunu artırmaktadır. Yapının sahne duvarları en hasarlı bölümüdür. Yapının sahne (proskenion) kısmının hemen üzerine inşa edilmiş olan yolun kendi yükü ve trafik yoğunluğu yapı duvarlarına basınç uygulamaktadır. Duvardaki çökmeler kazı çalışmaları yürütülürken tespit edilmiştir. Yol ile yapı duvarları arasındaki toprağı tutmak amacıyla yapılmış olan tuğla duvarlar geçici sağlamlaştırma müdahaleleridir (G. 11). 


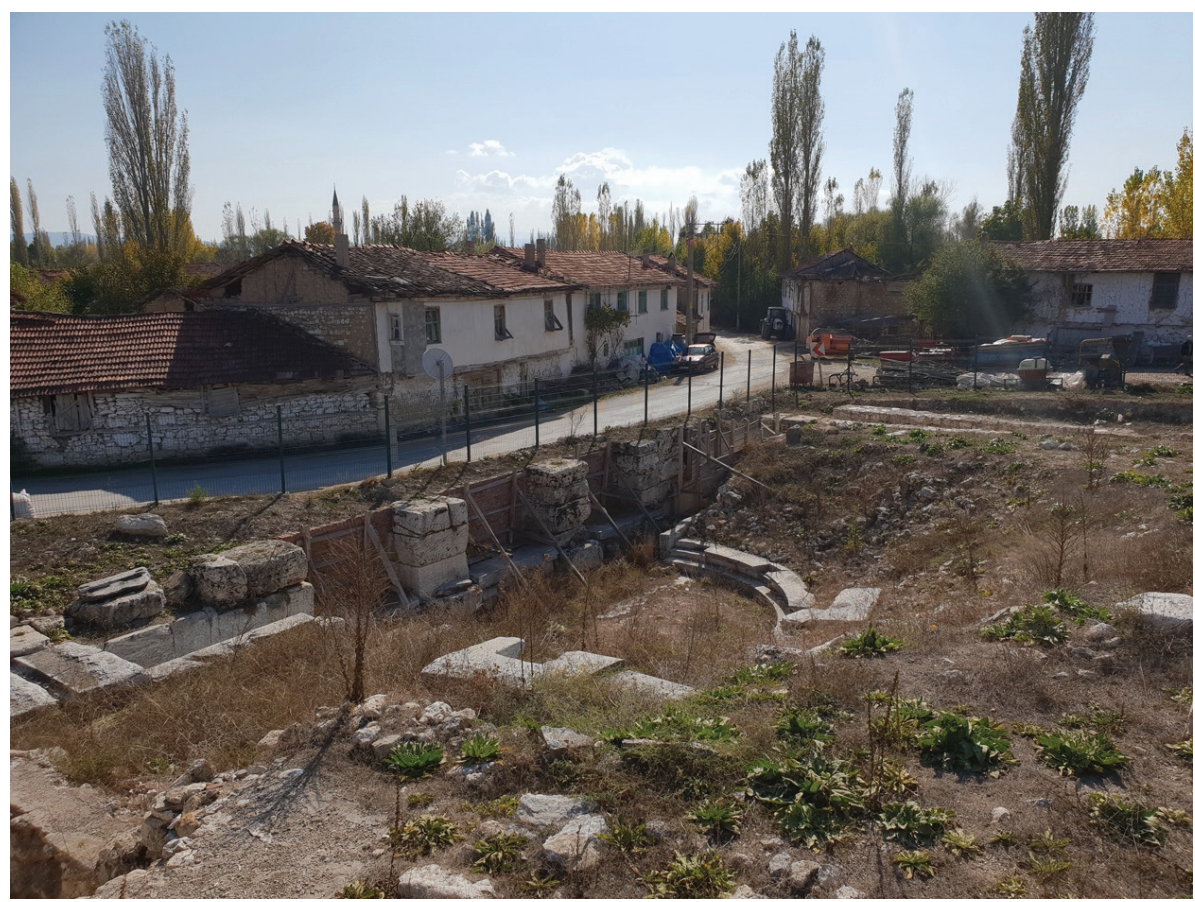

G. 11: Odeion yapısı ve kent dokusuyla ilişkisi (Kahraman, 2019).

Yolun kullanımından kaynaklanan titreşim, yapının tümünde hasara sebep olmaktadır. Sahne duvarlarının büyük blok taşlardan oluşan 4 sırası ancak günümüze ulaşabilmiştir. Sahne duvarlarındaki kalker taşlarda iklimsel koşullara bağlı olarak yüzey kaybı, taşların birleştiği kısımlarda ise derz kayıpları mevcuttur. Ayrıca taş bloklarda parça kayb1, çatlak ve oyuklanma gibi hasarlar da gözlemlenmektedir ${ }^{27}$ (G. 12). Yap1 elemanları arasında oluşmuş yüzey kayıplarına taşlar sıkıştırılarak birtakım müdahaleler yapılmıştır. Ancak kalıcı bir müdahale olmadığı için yapıyı korumaya yönelik bir sonuç vermemiştir. Bu müdahaleler çimento esaslı harç kullanılarak yapılmıştır (G. 12). Yapı duvarlarının bazı bölümlerinde de duvar dokusu ile uyumsuz, farklı malzemeler ile tümlemeler yapılmıştır.

27 ICOMOS-ISCS, Illustrated Glossary On Stone Deterioration Patterns, ICOMOS International Scientific Committee for Stone (ISCS). 

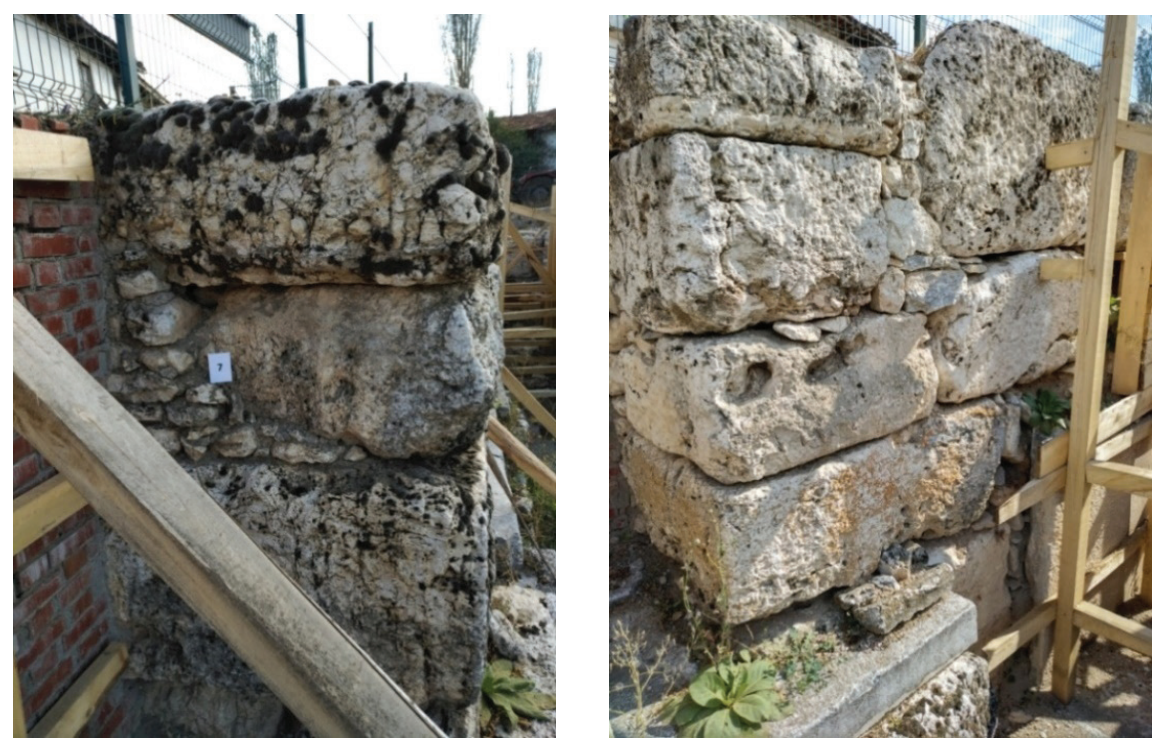

G. 12a ve G. 12b: Yapı malzemesindeki oyuklanma, çatlak ve kayıplar ile yapılan müdahaleler (Acun Özgünler, 2017).

Arkeolojik kazı çalışmalarında yapının caveasının yalnızca 2 oturma sırası in-situ olarak günümüze ulaşmışken; üç ve dördüncü sıraların izlerini gösteren mermer basamaklardan birkaçı yerinde bulunmaktadır. Diğer tüm oturma sıraları kayba uğramıştır; yalnızca oturma sıralarının altındaki moloz dolgu yapı alanını gösteren izlerdir (G. 4). Moloz temel dolgusunun üzeri ve arası toprak ile kapanmış ve bitkilenmeler oluşmuştur. Taşlar arasındaki harç kayıpları sebebiyle, moloz taş dolgular boşta durmaktadır; zamana ve iklimsel koşullara bağlı olarak duvar örgüsü dağılmaktadır (G. 13).

Paradoi ve koridorlarda derz kaybı bulunan, dağılmak üzere olan duvarları ayakta tutabilmek amacıyla çimento esaslı müdahalelerin yapılmıştır. Geleneksel yapı malzemesi ile uyumsuz olan ve özgün yapı malzemesine hasar veren bu onarımlar da zamanla aşınmıştır (G. 14). Güneydoğudaki paradoi kuzeydekine göre daha hasarlı durumdadir (G. 8). 


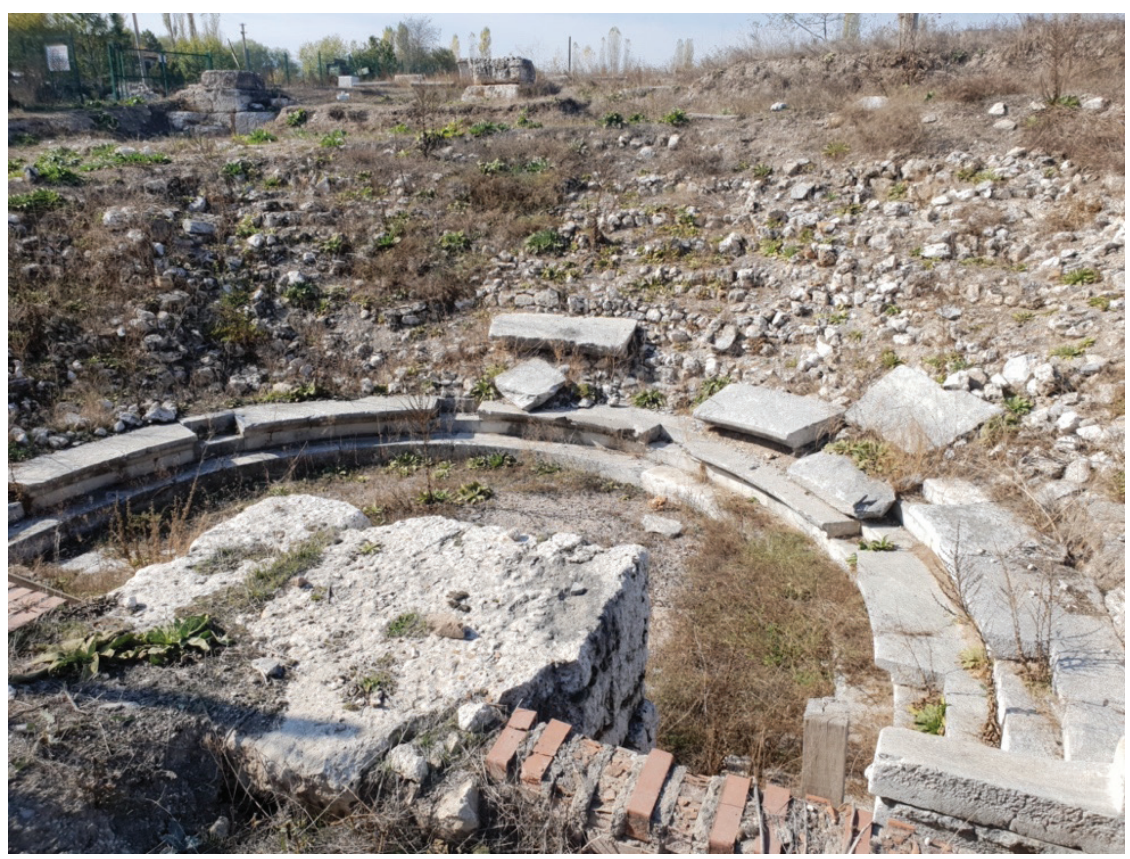

G. 13: Sahneden caveaya bakış (Kahraman, 2019).

Yapının döşeme kaplamalarının büyük bir kısmı kayba uğramıştır, günümüze ulaşmış olanlar ise hasarlı durumdadır. Paradoi kısmındaki döşemelerin ise üzerinde bulunan mermer örtü sayesinde korunmuş olduğu görülmektedir. Paradoinin üst örtüsünde de yer yer yüzey ve parça kayıpları mevcuttur ve mermerler yerinden hareket etmiş vaziyettedir. 


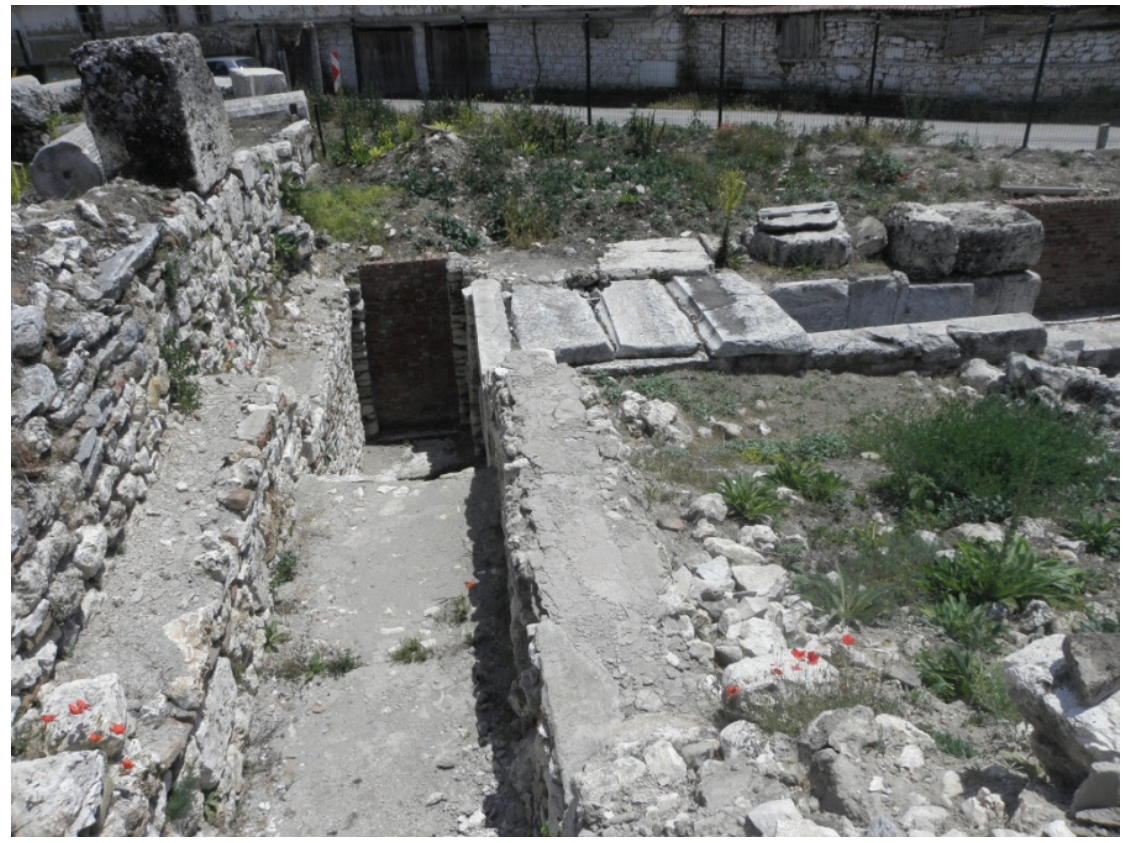

G. 14: Yapı duvarları üzerindeki çimento esaslı harç tabakaları (Acun Özgünler, 2017).

Genel olarak tüm yapı duvarlarında yüzey kirliliği görülmektedir. Bazı alanlar ise liken ile kaplanmıştır; bu biyolojik oluşumlar yapı malzemesinde kayba sebep olmuştur. Ana yapıyı oluşturan duvarlar derzsiz olarak inşa edilmişken önlerinde mermer kaplama olduğu düşünülen üst avluya geçiş sağlayan koridorların iç cidar duvarları ancak korunarak günümüze ulaşmıştır. Kaba yonu moloz taş duvar tekniğinde yapılmış olan bu duvarlarda yoğun derz kaybı gözlemlenmektedir. Derz araları toprak ile dolmuş, derz kaybı bulunan bazı bölgelerde ise yapı elemanları arasında boşluklar meydana gelmiştir. Yağmur suyu, kar ve dona maruz kalan bu bölgelerden, suyun yap1 iç bünyesine girmesi daha fazla hasar meydana getirmektedir. Boşluklara ilerleyen suyun hacmi, sıcaklık farklılıklarında donma-erime döngüsü sırasında değişmekte; yapı elemanlarında patlama ve çatlaklara neden olmaktadır. ${ }^{28}$

Yapıda yoğun derecede derz kaybı mevcut olduğu için özgün duvar harcına rastlamak çok güçtür. Son dönemde yapılmış olan onarımların da çimento esaslı harç ile yapılmış olduğu belgelenmiş, yapının farklı kısımlarından alınmış olan harç örnekleri laboratuvar ortamında deneysel çalışmalarla incelenmiştir. Ancak restorasyon uygulaması sırasında yapıdaki temizlik ve söküm çalışmalarının ardından duvar iç cidarında özgün harca ulaşıldığında, malzeme analizlerinin tekrarlanması gerekmektedir.

28 ICOMOS-ISCS, Illustrated Glossary On Stone Deterioration Patterns, ICOMOS International Scientific Committee for Stone (ISCS), 10. 


\section{Sonuç}

Antik Aizanoi kentinin ilk inşa dönemi MS 1. yüzyılın sonları ile 2. yüzyılın başlarına tarihlendirilen Odeion yapısı MS 4. yüzyılda yapılan müdahaleler ile son formunu almıştır. Yapıda gerçekleştirilen arkeolojik kazılardaki veriler ile yapı kalıntılarından alınan malzeme örnekleri üzerinde yapılan deneysel çalışmalarla yapı malzemelerinin özellikleri ve farklı dönem müdahaleleri tespit edilebilmektedir. Yapının ilk yapıldı̆̆1 döneme ait olduğu düşünülen caveasından alınan taş örneği ile orkestra bölümünden alınan zemin taşı örnekleri benzer özellikler taşımaktadır. Metamorfik bir kayaç olan gri ve beyaz damarlı bu mermer elemanların fiziksel ve kimyasal analiz sonuçları da bunu doğrulamaktadır. Arkeolojik kazı çalışmaları sırasındaki tespitlerde paradoinin üst ve yan kısımlarındaki profilli taşların devşirme malzeme olarak yapıda kullanıldıkları, yapının ilk yapıldığı döneme ait olan mermer elemanlardan farklı olduğu belgelenmiştir. Malzeme analiz deneylerindeki sonuçlarda da bu elemanların beyaz renkli, yer yer siyah damarlara sahip porozitesi düşük özellikte oldukları görülmüştür. Bu elemanların fiziksel özellikleri de gri ve beyaz damarlı olan mermer yapı elemanlarından farklı olup düşük basınç dayanımına sahiptirler.

Sahne kısmındaki duvarlar mikritik dokulu açık krem renkli kalker taşları ile farklı bir dönemde inşa edilmiştir. Blok taş şeklinde uygulanmış olan bu taşların birbirine kenetlenerek uygulandığı ancak hemen arkasında yer alan yolun varlığından dolayı arkeolojik çalışmalarla birlikte desteklendiği görülmüştür. Farklı özellikteki taşlar ile yapılmış olan bu kısmın arkeolojik kazı ve tespit çalışmalarında MS 4. yüzyıla ait olduğu düşünülmektedir.

1998 yılından itibaren devam eden kazı çalışmaları sırasında açığa çıkarılan yüzeyleri ve yapı elemanlarını sağlamlaştırmak amacıyla birtakım onarım müdahaleleri yapılmıştır. Yapıdan alınan harç örnekleri üzerinde gerçekleştirilmiş olan deneysel çalışmalarda bu onarımların çimento ve kireç esaslı melez harçlar ile yapıldı̆̆ı görülmüştür. Bu müdahalelerin yapıyı ayakta tutabilmek için kısa zamanda ve geçici onarımlar olduğu bilinmektedir. Bu onarımlar sayesinde de yapı büyük oranda günümüze ulaşmıştır. Geç dönemde yapıya eklenmiş olan duvar kalıntısında da tuğla kırığ1 agregalı horasan harcı ile örgünün oluşturulduğu ve Bizans dönemi müdahalesi olduğu düşünülmektedir.

Yapının konsolidasyonu için birtakım müdahaleler yapılmış olmasına karşın derz kayb1, yüzey kayb1, bitkilenme, liken oluşumu, oyuklanma gibi hasarlar mevcuttur. İklimsel koşullara açık durumda olan yapıda bu hasar derecelerinin yapılan 20172019 yılındaki izlemelerde zamana bağlı olarak arttığı görülmektedir. Caveanın temel dolgusu ile sahne kısmındaki taşlar dağılmak üzeredir. Yapının çevresinde özgün yapı taşları da kayba uğramış olduğu için anastylosisin yapılabilmesi mümkün gözükmemektedir. Helenistik döneme ait olan odeion yapıları özel bir yapı tipidir. Özgün 
yapıdan ancak bir kısmı günümüze ulaşmış olan Aizanoi odeionun sürdürülebilirliğinin sağlanması ve yapının daha fazla kayba uğramaması için acil koruma önlemleri alınmalıdır.

Yapı tümüyle toprak ile kaplı durumdadır, zaman içinde rüzgâr ile birlikte taşınan toprak, yapı elemanlarının üzerini kapatacaktır. Yapıya ilişkin restorasyon müdahaleleri yapılmadan önce yapıyı kaplayan toprak tabakasının itinalı bir şekilde temizlenerek yapıdan uzaklaştırılması gerekmektedir. Bu çalışmalar sürdürülürken, alandaki ve yap1 elemanları üzerindeki bitkiler de itinalı bir şekilde temizlenmeli ve tekrar oluşmaması için bitki öldürücü kimyasal ilaçlarla ilaçlanmalıdır. Bitki oluşumu görülen yerlerde "Herbisit" yosunlaşma, alg, liken görülen yerlerde "Algisit" olarak bilinen ilaçlar kullanılabilir. Bu tür ilaçlar \%2'lik konsantrasyonda yok edilmesi istenen bitkilerin üzerine püskürtme, sünger veya firça gibi bir malzeme ile uygulanmalıdır. Ancak bu uygulamadan önce yüzeyler toz ve kirden arındırılmalıdır. Uzun bitkiler kesilmeli ve sonrasında ilaç uygulaması yapılmalıdır. Yapı duvarlarında da yoğun derecede bulunan kirlilik, liken gibi oluşumların tümleme, derz onarımı gibi müdahalelere başlamadan önce yapı duvarlarını açığa çıkarabilmek amacıyla temizlenmesi önerilmektedir.

Uygulamanın yapılacağı zamana bağlı olarak uygun yüzey temizlik teknikleri seçilmelidir. Onarım çalışmaları kış aylarında yapılacak ise sulu yüzey temizlik uygulamalarında dikkatli olunmalıdır. Suyun yüzeyde kuruyamayacağ iklimsel koşullarda, yapı duvarının iç bünyesine doğru nüfuz edeceği ve daha fazla hasara neden olacağı düşünülerek kuru temizlik yöntemleri tercih edilmelidir (mikro kumlama, lazer yöntemi ile temizlik gibi). Özellikle inatçı kir tabakalarının temizliğinde önerilen mikro kumlama ile temizlik uygulaması ince kalsit agrega ile 1-1,5 atm basınç uygulayarak kontrollü bir şekilde yapılabilir.

Temizlik uygulamalarının ardından yapı duvarları açığa çıkarılabilecek ve dolgu malzemelerinin durumu tespit edilebilecektir. Yapı duvarları üzerinde şap şeklinde uygulanmış olan çimento esaslı harçların özgün malzemeye zarar vermesi sebebiyle itinalı bir şekilde raspa edilerek yüzeyden uzaklaştırılması gerekmektedir. Moloz taş duvarlardaki çimentolu onarımların durumları restorasyon çalışmaları sırasında değerlendirilmeli, bu onarımların sökülmesi sırasında daha fazla kayba sebep olunacağı düşünülüyorsa müdahale edilmemelidir.

Derz kaybı bulunan kısımlarda hasar durumunun artmasını engellemek ve mevcut duvar dokusunu olduğu gibi koruyabilmek amaciyla harç reçetesine göre derz onarımları yapılmalıdır. Yapıdan alınmış olan harç örnekleri üzerinde yapılmış analizlere göre derz harcı olarak; 1 kısım hidrolik kireç (3,5 MPa), 2 kısım 6mm elek altı dere çakı1ı veya taş kırığı, 1 kısım $2 \mathrm{~mm}$ elek altı dere kumu karışımı uygun görülmektedir. Derz onarımları yapılmadan önce yüzeyin iyice temizlenmiş olduğuna dikkat edilme- 
lidir. Harçlı onarımların çatlamalara sebep olmaması için, hava sıcaklığının $10^{\circ} \mathrm{C}$ 'nin altında olduğu durumlarda uygulamanın yapılmamasına dikkat edilmelidir.

Oturma siralarındaki moloz dolgu tabakası da doğrudan toprak katman üzerine oturmaktadır. Bu durumda taşlar hareketli durumda olmakta ve iklimsel koşullar ile çevreye dağılmaktadır. Yapının izlerini devam ettirebilmek ve yapı algısını koruyabilmek amacıyla hidrolik kireç esaslı harçlar ile bir dolgu yatağı oluşturulmalı moloz taşların bu yatağa oturtularak korunması önerilmektedir.

Paradoi kısmındaki döşemeler büyük oranda sağlam durumdadır. Deformasyona uğramış mermer elemanların terazisine getirilerek uygun harç karışımı ile yatak oluşturularak mevcut yerlerine yerleştirilmesi gerekmektedir. Mermerlerde oluşmuş ve oluşmakta olan kılcal çatlaklara şırınga vb. aletler ile \% 7'lik akrilik emülsiyon kullanılarak enjeksiyon yöntemiyle sağlamlaştırma yapılması; mikro çatlaklar için 1 kısım hidrolik kireç (NHL 3,5 MPa), 1,5 kısım 250-500 mikron elek altı boyutlarında taşın renginde mermer tozu karışımı, jel kıvamına getirilerek \%5'lik akrilik emülsiyon ilavesi ile hazırlanan harcın, şırınga vb. enjeksiyon aletleri ile sağlamlaştırma yapılması önerilmektedir. Akrilik emülsiyonların Metil trimetoksi silan (MTMOS)'ta çözülerek kullanılması, adhezyon özelliği sağladığından tercih edilmiştir. ${ }^{29}$ Akrilik reçineler uygun hava sıcaklığında uygulandığında epoksi ve polyester reçinelere göre daha iyi dayanım göstermektedirler. ${ }^{30}$ Mermer bloklarda görülen çatlakların veya parça kayıplarının onarımından önce yüzeylerine temizlik uygulanmalıdır. Mermerlerin temizliğinde hafif kirlilikler için öncelikle plastik tırnak firçaları ile kuru temizlik yapılmalıdır. Sonra non-iyonik deterjanlı su ile 1slatılmış firçalar ile tüm yüzeyler silinmelidir.

Sahne kısmında da mermer elemanların birçoğu mevcut durumdadır ancak yitik durumda olan döşeme taşlarının yerleri toprak ile kaplanmış ve bitkilenmeler oluştuğu için mevcut döşeme taşlarını korumak amacıyla hidrolik kireç esaslı ince bir şap tabakası yapılarak bu kısmın konsolide edilmesi önerilmektedir.

Günümüzde Çavdarhisar kırsal alan yerleşimi Aizanoi antik kenti ile iç içe durumdadır (G. 2). Antik kentin korunması için mimari koruma önlemleri ile birlikte halkın da korumaya katılımını sağlamak için eğitim ve tanıtım faaliyetlerinin de düzenlenmesi önerilmektedir. Kültür turizminde çok önemli bir yere sahip olan ve 2012 yılında UNESCO Dünya Mirası Geçici Listesi'nde yer alan Aizanoi kenti Anadolu'da en iyi korunmuş Zeus Tapınağı'na sahiptir. Turizm ve tanıtım faaliyetlerinin artırılarak antik kentin kırsal yerleşim ile bir arada ziyaretini sağlayacak bir gezi aksı oluşturulması,

29 Raffaelle Rossi-Manaresi, "Treatments for Sandstone Consolidation”, The Conservation of Stone I, Proceedings of the International Symposium, (Bologna: ICCROM,1975), 547-571.

30 Jonathan Kemp, "Fills for the Repair of Marble, A Brief Survey." Journal Of Architectural Conservation 2/15 (2009): 59-78. 
turizm için tesisler düzenlenmesi bu alanların korunması için fayda sağlayabilecek uygulamalardandir.

Hakem Değerlendirmesi: Dış bağımsız.

Çıkar Çatışması: Yazarlar çıkar çatışması bildirmemiştir.

Finansal Destek: Bu çalışmadaki analiz verilerinde, 2017-328 Proje numarası ile İstanbul Teknik Üniversitesi Döner Sermaye İşletmeleri Yönetmeliği'ne göre hazırlanmış olan Prof. Dr. Seden Acun Özgünler>in teknik raporu esas alınmıştır.

Teşekkür: Bu çalışmaya katkı sağlayan Dr. Deniz Aslan ve Y.Mimar Sevinç Aslan’a sonsuz teşekkürlerimizi sunarız.

Peer-review: Externally peer-reviewed.

Conflict of Interest: The authors have no conflict of interest to declare.

Grant Support: The analysis data in this study was based on the technical report of Prof. Dr. Seden Acun Özgünler, which was prepared by the Istanbul Technical University Revolving Funds Regulations with Project number 2017-328.

Acknowledgement: The authors owe a debt of gratitude to Dr. Deniz Aslan ve MSc. Architect Sevinç Aslan.

\section{Kaynakça/References}

Adam, Jean-Pierre. Roman Building: Materials and Techniques. Çev. Anthony Mathew, London: A. Taylor and Francis Group, 1980.

Anabolu, Mükerrem Usman. İstanbul ve Anadolu'daki Roma Imparatorluk Dönemi Mimarlı Yapttlar. İstanbul: Arkeoloji ve Sanat Yayınları, 2001.

Ashurst, John. Conservation of Ruins. Oxford: Butterworth-Heinemann, 2007.

Ashurst, John ve Francis G. Dimes. Conservation of Building \& Decorative Stone. Oxford: Butterworth-Heinemann, 1998.

Barker, Andy. Introduction to Metamorphic Textures and Microstructures. United Kingdom; Stanley Thomes Ltd, 1998.

Bieber, Margarete. The History of The Greek and Roman Theater. Princeton, New Jersey: Princeton University Press, 1961.

Cartwright, Mark. "Phrygia". World History Encyclopedia. Erişim 2 Haziran 2021. https://www. worldhistory.org/ phrygia.

Cartwright, Mark. Stadium. World History Encyclopedia. Erişim 2 Haziran 2021. https://www. worldhistory.org/ stadium.

Davis, Edwin John. Anadolu, 19. Yüzyılda Karya,Frigya, Likya ve Pisidya Antik Kentlerine Yapılan Bir Gezinin Öyküsü. Çev. Funda Yılmaz. İstanbul: Arkeoloji ve Sanat Yayınları, 2006.

Ertaş, Mustafa. Çavdarhisar Aizanoi Antik Kenti. Kütahya: Express Matbaası, 2010.

ICOMOS-ISCS, Illustrated Glossary On Stone Deterioration Patterns, ICOMOS International Scientific Committee for Stone (ISCS).

Kemp, Jonathan. "Fills for the Repair of Marble, A Brief Survey." Journal Of Architectural Conservation 2/15 (2009): 59-78.

Özer, Elif. «Aizanoi 2016 Sezonu.” 39. Kazı Sonuçları Toplantısı, 22-26 Mayıs 2017. c. 3. Bursa: T. C. Kültür ve Turizm Bakanlığı, Kültür Varlıkları ve Müzeler Genel Müdürlüğü, 2017, 207-227.

Özer, Elif ve Hatice Korkmaz. «Tarihsel Süreçte Aizanoi Kentindeki Dört Yapıda Tahrip ve Koruma.” Pamukkale Üniversitesi Sosyal Bilimler Enstitüsü Dergisi 18 (2014): 11-20.

Öztürk, Deniz Başar. «Troas Bölgesi Odeion Yapıları.” Doktora Tezi, Çanakkale Onsekiz Mart Üniversitesi, 2006. 
Rheidt, Klaus. "Die Ausgrabungen In Aizanoi 2001; Aizanoi 2001 Yılı Kazı ve Onarım Çalışmaları" 24. Kazı Sonuçları Toplantısı, 27-31 Mayıs 2002. c. 2. Ankara: T. C. Kültür Bakanlığı Yayınları, 2002, 315-326.

Rheidt, Klaus. "Die Ausgrabungen in Aizanoi 2002, Aizanoi 2002 Yılı Çalışmaları.” 25. Kazı Sonuçları Toplantısı, 26-31 Mayıs 2002. c. 1. Ankara: T. C. Kültür Bakanlığg Yayınları, 2003, 127-138.

Rheidt, Klaus. Aizanoi und Anatolien. Neue Entdeckungen zur Geschichte und Archäologie im Hochland des westlichen Kleinasien. Mainz: Verlah Philip von Zabern, 2010.

Riorden, Elizabeth. "A Hadrianic Theater at Ilion (Troy): a Paradigm Shift for Roman Building Practice and Its Aesthetic Aftermat." Proceedings of the Second International Congress on Construction History, 3. USA: Cambridge University, 2006, 2635-2651.

Rossi-Manaresi, Rafaella. "Treatments for Sandstone Consolidation.” The Conservation of Stone I, Proceedings of the International Symposium. Bologna: ICCROM, 1975, 547-571.

Thorpe, Martin. Roman Architecture. London: Bristol Classical Press, 1995.

Google maps. "Çavdarhisar” Erişim 26 Ağustos 2020. https://www.google.com.tr/maps/place/ Cavdarhisar 
